\title{
Evaluation of the behavior of brick tile masonry and mortar due to capillary rise of moisture
}

\author{
M.S. Camino ${ }^{\mathrm{a}} \bowtie$, F.J. León ${ }^{\mathrm{a}}$, A. Llorente ${ }^{\mathrm{a}}$, J.M. Olivar ${ }^{\mathrm{a}}$ \\ a. Universidad de Valladolid (Valladolid, Spain) \\ \mcamino@arq.uva.es
}

Received 8 April 2013

Accepted 20 January 2014

Available on line 03 June 2014

\begin{abstract}
For a better understanding of the behaviour of old brick masonry in facing the rising damp problem, multiple tests were made in the laboratory: water absorption, moisture content, apparent porosity, temperature and thermal camera imaging on brick masonry and its components: brick and mortar. This has allowed us to determine which of the previous tests is the best in predicting the behaviour of a real wall. In addition, the tests have also helped in defining a process to evaluate the moisture content of walls in a buildings, which is important for heritage restoration projects.
\end{abstract}

KEYWORDS: Brick; Brickwork; Rising damp; Absorption; Thermography

Citation / Citar como: Camino, M.S.; León, F.J.; Llorente, A.; Olivar, J.M. (2014). Evaluation of the behavior of brick tile masonry and mortar due to capillary rise of moisture Mater. Construcc. 64 [314], e020 http://dx.doi.org/10.3989/ mc.2014.02513.

RESUMEN: Evaluación del comportamiento de las fábricas de ladrillos de tejar y argamasa debido a la humedad que asciende por capilaridad. Para un mejor conocimiento del comportamiento de las fábricas antiguas de ladrillo frente a la ascensión capilar de agua, se han realizado en laboratorio ensayos de absorción de agua, de contenido de humedad, de porosidad aparente, de temperatura e imágenes con cámara termográfica sobre muros de fábrica y sus materiales componentes: ladrillo y argamasa. Ello ha permitido inferir cuál es el ensayo realizado a los ladrillos que mejor predice el comportamiento del muro real. También ha permitido definir un procedimiento para evaluar el contenido de humedad de fábricas existentes, importante para los proyectos de restauración del patrimonio construido.

PALABRAS CLAVE: Ladrillo; Fábrica de ladrillo; Ascensión capilar; Absorción; Termografía

Copyright: (C) 2014 CSIC. This is an open-access article distributed under the terms of the Creative Commons Attribution-Non Commercial (by-nc) Spain 3.0 License.

\section{INTRODUCTION}

The research on the behavior of old brick masonry against capillary rise of moisture, brings about the need to know the exact behavior of each components that make up these walls: ceramic bricks and air-entrained hydrated lime mortar.

The theoretical analysis that study the capillary rise of water can be of use to us to know this process when it comes to homogeneous constructive elements, but this is not the case with brick masonry which are made up of two materials: bricks and mortar, with each having different characteristics, causing this capillary rise not to be linear or uniform.

The classic expression of capillary rise is by Jurin, by which the height reached within a capillary tube depends on the surface tension, of the wettability or the angle created by the surface of the liquid with the wall of the tube, capillary radius, density of the liquid and gravity. 
However, when consideration a real wall this requires an approach that allows to take into consideration other factors that can determine more clearly the scope of this phenomenon. In this sense, Mason (1) developed a model by which capillary rise is conditioned by the nature of the capillary pores, the wall thickness and its evaporation rate. In addition from a series of tests, he related the influence of age to greater absorption/ permeability of masonry mortar.

In 2002, Hall and Hoff (2) proposed a new model which states that the height of capillary rise $(\mathrm{H})$ in a wall is proportional to the absorption of water by the mortar (S), and to the square root of the ratio of the wall thickness (b) and twice the product of the evaporation rate per unit of wet area (e) and the volume of water per unit of volume of the material $\left(\theta_{\mathrm{w}}\right)$. The formula $\mathrm{H}=\mathrm{S}\left(\mathrm{b} / 2 \mathrm{e} \theta_{\mathrm{w}}\right)^{1 / 2}$ is complicated to apply in the case of brick masonry walls with thick mortar joints because except $b$, the thickness of the wall, in our case it's a foot, the rest of variables are difficult to evaluate because they are affecting two different materials in imprecise environmental conditions.

Subsequently, Risch (3), in an estimable attempt to approach the real situation, revealed the difficulty to obtain actual data by direct measurements of the walls in order to check the validity of the theoretical formulations. The model Hall and Hoff did is based on the theory of unsaturated flow, like what happens in the complex porous structure of a brick wall, it predicts theoretical situations consistent with field observations. However, the same work shows the difficulty to carry out measurements that allows us to verify the approximation to these theoretical predictions. He also notes the uncertainty resulting from the parameter of sorptivity (absorption coefficient), given the difference in permeability of the brick and mortar, their age and the possible presence of sulfates. In his tests, he used different types of mortar and the masonry is joint with thin mortar and the bricks are quiet thick, because he wanted to verify the importance of mortar in the processes of absorption. And one of the conclusions reached is that there is a big difference between the results of the formulas used to calculate the level to which moisture can reach and the real tests on masonry.

More recently Peixoto (4) notes that due to the complexity of the problem it is extremely difficult to present scientific explanations for various forms of capillary rise and together with theoretical studies that he carried out with various tests mainly on stone walls with different concrete facing reached a conclusion on the absorption process and drying process of the masonry. He establishes the factors that influence rising damp: environmental weather conditions, sunlight, presence of sulfates, porosity and porometry of the material, wall thickness and facing material, and he defines a technique for when intervening in the rehabilitation of historic buildings which is already used in various restoration work. It is based mainly in preventing the damp rising in the building by using barriers, and in the providing a network of cavities with controlled ventilation depending on the moisture, to regulate the drying process (5) at the base of the walls, since he concludes that the density of the flux $g\left[\mathrm{~kg} /\left(\mathrm{m}^{2} \cdot \mathrm{s}\right)\right]$ is calculated according to the surface transfer coefficient of moisture $\beta$ in $\mathrm{m} / \mathrm{s}$ and the amount of water vapor on the surface $C^{\prime}$ and air $C^{\prime}{ }_{a}$ in $\mathrm{kg} / \mathrm{m}^{3}$ using the formula $\mathrm{g}=\beta\left(\mathrm{C}_{\mathrm{s}}^{\prime}-\mathrm{C}^{\prime}\right)_{\mathrm{a}}\left[\mathrm{kg}\left(\mathrm{m}^{2} \cdot \mathrm{s}\right)\right]$. Another conclusion he reaches is that the process may have limitations when the walls are not homogeneous (6), as is the case with a brick wall.

The main objective of this research, based on the results of the studies aforementioned, is to evaluate which of the tests done with bricks and mortar provides the most reliable and accurate for the study of the behavior of masonry walls. Another objective is to find a procedure that allows to assess the moisture content and the process of capillary rise of water in old brick walls by conducting tests of the individual materials of the walls and measurements "on site" of the temperature and humidity, with probes and thermal imaging camera; all as previous steps to the decision-making in a restoration project.

\section{MATERIALS AND WORK METHODOLOGY}

Since the research is to know the state of old masonry, we opted on using brick tile from demolition and sufficient number for tests were found in Serrada (Valladolid). Some have the brand of the roof builder "La Operaria" and are more than 100 years old. Old masonry was made of lime mortar and sand and because it was not possible get specimens of mortar from the old demolished buildings because it's not possible to retain the mortar joints, specimens have been made with lime and sand in the proportion three to one (7) with air-entrained hydrated lime mortar type CL 90S (calcium hydroxide) and washed sand river, silica. In order to compare results of the old bricks with other solid bricks, tests have also been made with solid bricks that are currently being manufactured with the appearance that imitates the old masonry, and these came from the brick factory Santoveña, Santander.

Once the materials were selected: bricks, lime and sand two types of tests were made: to know the dimensions, apparent density and porosity, and others related to water absorption.

The dimensions of the bricks, length $\times$ width $\times$ height, in $\mathrm{mm}$ were measured in accordance with the UNE-EN 772-16 (8), the apparent dry density according to the UNE-EN 772-13 (9), and the percentage of channels/spaces or porosity UNE 772-3 (10). The mortar specimens were made of $40 \times 40 \times 160 \mathrm{~mm}$ and the apparent density and the 
percentage of visible pores was obtained by tests according to the UNE-EN 1015-10 Test Methods for mortar for masonry. Part 10: Determination of apparent dry density of dry mortar.

Determination of water absorption was made according to various standards in order to compare the results of the tests carried out on the bricks to the walls made of these bricks allowing us to determine which of the test results obtained were nearest the real situation. Different UNE tests regarding water absorption were used are:

UNE EN 15801 Conservation of cultural heritage. Determination of the capillary water absorption. The test procedure was as follows: at the bottom of a container was placed a dry permeable base of about $6 \mathrm{~mm}$ thick. Water was added until the bed was saturated, and the liquid level was kept constant throughout the test, adding water when necessary. The specimens of dried brick and mortar, were placed on the base and were weighed at intervals to determine amount of absorbed water. The test was carried out with samples of the two types of bricks and mortar:

- Specimen of old solid brick tile, dimensions $258 \times 128 \times 47 \mathrm{~mm}$ for the test the brick was laid on the smaller side of $0.006016 \mathrm{~m}^{2}$.

- Specimen of modern semi-handmade bricks of dimensions $233 \times 108 \times 38 \mathrm{~mm}$ for the test the brick was laid on the smaller side of $0.003564 \mathrm{~m}^{2}$.

- Specimen of mortar, dimensions $40 \times 40 \times$ $160 \mathrm{~mm}$, hydrated lime and river sand $1: 3$, to carry out the test the mortar was laid on the smaller side, $0.0016 \mathrm{~m}^{2}$.

The test provides the coefficient of capillary water absorption AC which is represented by a curve obtained by plotting the change in mass per unit area $\mathrm{Q}_{\mathrm{i}}$ in relation to the square root of time $t_{i}^{1 / 2}$, and is calculated by linear regression using at least five points aligned with

$$
\mathrm{Q}_{\mathrm{i}}=\left(\mathrm{m}_{\mathrm{i}}-\mathrm{m}_{\mathrm{o}}\right) / \mathrm{A} \text { en } \mathrm{kg} / \mathrm{m}^{2}
$$

where $\mathrm{m}_{0}=$ mass of the dry specimen $(\mathrm{Kg})$; $\mathrm{m}_{\mathrm{i}}=$ mass of the specimen in time $\mathrm{t}(\mathrm{kg}) ; \mathrm{A}=$ surface area in contact with water $\left(\mathrm{m}^{2}\right)$.

UNE-EN 772-11: Methods of test for masonry units. Determination of water absorption by capillarity for masonry elements, concrete, natural and artificial stone, and the initial rate of water absorption of clay bricks for masonry. The test was performed on samples of the same types of bricks. Allowed to dry in an oven at a temperature of $105^{\circ} \mathrm{C}$ to a constant weight. Then left to cool at room temperature and then measure the dimensions of each of the faces which would then be submerged in the test to calculate gross area of absorption. They were then placed on small supports so that the lower part did not touch the bottom and remained submerged at a depth of $5 \mathrm{~mm}$. After the specified time, 1 minute, the specimens were removed, the surface water was dried and then they were weighed. The initial rate of absorption of each brick is calculated using the following fomula:

$$
\begin{aligned}
\mathrm{C}_{\mathrm{wi}, \mathrm{s}}= & 10^{3} \times\left(\mathrm{m}_{\mathrm{sos}, \mathrm{s}}-\mathrm{m}_{\text {seco, }, \mathrm{s}}\right) / \mathrm{A}_{\mathrm{s}} \mathrm{t} \text { en kg} / \\
& \left(\mathrm{m}^{2} \times \text { min }\right) \text { where } \mathrm{t}=1 \mathrm{~min}
\end{aligned}
$$

Where: $\mathrm{C}_{\mathrm{wis}}$ is the initial rate of water absorption, $\mathrm{m}_{\mathrm{so}, \mathrm{s}}$ the mass after the immersion, $\mathrm{m}_{\text {seco,s }}$ the mass after drying, $A_{s}$ the surface area and time which is equal to 60 seconds.

Although the test is for masonry elements it has also been conducted on mortar specimens of $40 \times 40 \times 160 \mathrm{~mm}$.

UNE-EN 1015-18: Methods of test for mortar for masonry. Part 18: Determination of water absorption coefficient by capillarity of dried mortar. Procedure: the absorption coefficient of water by capillarity was determined by immersing the cut face of the mortar specimen balanced on four supports at 5 to $10 \mathrm{~mm}$ height so as not to touch the bottom for a specified time with the vertical faces of the test pieces coated in paraffin. The water absorption coefficient of the 6 tested specimens was calculated, depending on the masses of the specimens after 10 minutes and ninety minutes of being deposited in the tray with water, from the following formula:

$$
\mathrm{C}=0.1(\mathrm{M} 2-\mathrm{M} 1)=1.22 \mathrm{~kg} /\left(\mathrm{m}^{2} \cdot \mathrm{min}^{0.5}\right)
$$

where, $\mathrm{C}$ is the absorption coefficient $\mathrm{kg} /\left(\mathrm{m}^{2} \cdot \mathrm{min}^{0.5}\right)$, M1 mass after 10 minutes immersion M2 mass after 90 minutes immersion.

Note that while the first of the standard used (UNE-EN 15801, published recently, has been drafted by the European Committee for Conservation of Cultural Heritage CEN_TC_346, and in principle, it seems indicated to determine the characteristics of the materials when it comes to a restoration proyects), the other two standards are intended to evaluate the characteristics of the materials for use in new buildings.

To find out how much water vapor from the atmosphere can penetrate materials by sorption, tests were conducted in a climatic chamber (model WEISS-WK 3) where bricks and samples of mortar joints were introduced after being dried at $105^{\circ} \mathrm{C}$, to a temperature of $20^{\circ} \mathrm{C}$ and constant relative humidity of $50 \%$ at a constant weight. The oven used in the laboratory is the model IBERTEST with forced convection and a temperature range of $0{ }^{\circ} \mathrm{C}$ to $200{ }^{\circ} \mathrm{C}$.

After the tests were carried out on the bricks, and to find out what happens with capillary rise on a brick masonry with mortar joints, tests were done 
on two brick masonry walls built in the laboratory: the first one $78 \times 28 \times 100 \mathrm{~cm}$, made with solid brick tiles, and the other one $65 \times 24 \times 100 \mathrm{~cm}$, made of solid modern brick (the different width of the two is due to the two being done with the same number of bricks per course 5 in a heading bond). The walls have the same number of courses, thirteen, the same height, and the thickness of the brick is different, so it was decided to have the courses of brick at the same height and the mortar joints of different thicknesses between 5 and $10 \mathrm{~mm}$, thicker for the modern brick masonry. These walls built on a sand bed of $5 \mathrm{~cm}$ thick, on a solid base with a waterproof sheet (Figure 1). The ambient temperature during the test was between $19{ }^{\circ} \mathrm{C}$ and $21^{\circ} \mathrm{C}$ and relative humidity between $45 \%$ and $55 \%$, measured with a probe type "Saveris H4D".

In the first tests performed on the walls sand in the raft was saturated with water which rose up the wall, allowing us to take measurements of the moisture content in the walls as a result of the capillary rise. The data collection procedure consisted in drilling holes of $8 \mathrm{~mm}$ diameter in the brick every two rows, penetrating up to the center of the walls, and to place type "Saveris H4D" probes to measure the temperature and humidity within the holes (11).

To determine the state of saturation of the bricks and mortar, the walls were demolished in an orderly manner once the moisture absorption was stabilized. During the demolition, the bricks and bits of mortar joints were weighed, after that

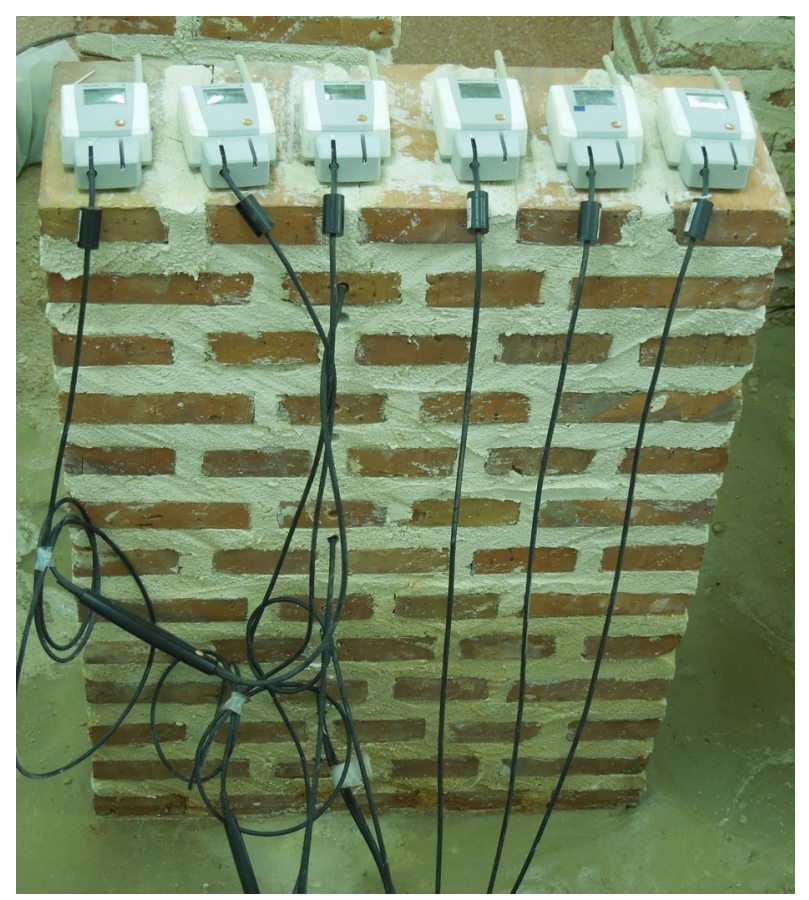

Figure 1. One foot brick tiles wall with moisture probes, standing on a bed of sand. they were dried in an oven which allowed to really know how much water the specimens had absorbed (bricks and mortar). While the bricks could be recovered wholly and were cleaned of the mortar, it was more laborious to obtain specimens of mortar, especially from the sides of the walls, so there is only data of the mortar of the central area walls.

Before demolition various images were captured with a FLIR ThermaCAM B29 thermal imaging camera with a thermal sensitivity of $0.1^{\circ} \mathrm{C}$, measuring range temperature $-20^{\circ} \mathrm{C}$ to $+100{ }^{\circ} \mathrm{C}$, spectral range 7.5 to $13 \mu \mathrm{m}$ and emissivity value of 0.9 , for brick.

\section{RESULTS AND DISCUSSION}

\subsection{Dimensions, apparent density and porosity of the materials}

Table 1 shows the results obtained after carrying out the tests on materials and testing standards:

The porosity of the two bricks is fairly close. These values are close to those found in other studies, in which the old bricks have water accessible porosity of $30.5 \%$ and modern bricks of $26.3 \%$, Fort (12) and within the range of porosity assessed by MOP (polarized light microscopy) of 15 to $30 \%$, Setti (13).

As seen by the results, the two types of bricks have different apparent densities the modern brick is similar to that of the mortar. The bricks presents values below the results of other researches, though the brick tiles density is lower $\left(1760 \mathrm{~kg} / \mathrm{m}^{3}\right)$ than the modern brick $\left(1915 \mathrm{~kg} / \mathrm{m}^{3}\right)$. With the microscope MOTIC SM2-168 500 $\times$ magnification and 2300 MOTICAM camera photographs have been made of the two blocks in which it can be seen that in the brick tiles the pores are larger than the modern brick (Figure 2).

\subsection{Water absorption of the materials}

In Table 2 are the results of absorption tests carried out on different materials according to the nomenclature and units used in each test standard.

The study of the data obtained in the abovereferenced tests shows that brick tiles have the lowest coefficient of capillary absorption when in contact with a wet base (closer to the real situation). In the UNE EN 772-11 test, traditional suction (partially submerged), the initial absorption rate turns out to be the higher in the two bricks.

Regarding the test according to the standard EN 15801 it is interesting to study the graph (Figure 3) of the process shown on the graph are the values of $\mathrm{Q}_{\mathrm{i}}$ in relation to $\mathrm{t}_{\mathrm{i}}^{1 / 2}$ during the six-day test. The first part in which the values are aligned make it possible to calculate AC. 
TABLE 1. Dimensions, density and porosity of the materials

\begin{tabular}{|c|c|c|c|c|c|}
\hline \multirow[b]{3}{*}{ Standar } & \multicolumn{3}{|c|}{ Dimensions (mm) } & \multirow[b]{2}{*}{ Density apparent $\mathrm{kg} / \mathrm{m}^{3}$} & \multirow[b]{2}{*}{ Porosity apparent $\%$} \\
\hline & Length (stretcher) & Width (header) & Height (cull) & & \\
\hline & \multicolumn{3}{|c|}{ UNE EN 772-16 } & UNE EN 772-13 & UNE EN 772-3 \\
\hline Brick tile & 279 & 140 & 48 & 1680 & 28.8 \\
\hline \multirow[t]{3}{*}{ Modern brick } & 233 & 108 & 38 & 1830 & 27.2 \\
\hline & \multicolumn{3}{|c|}{ Dimensions (mm) } & & \\
\hline & Length & Width & Height & Density apparent $\mathrm{kg} / \mathrm{m}^{3}$ & Porosity apparent $\%$ \\
\hline Standar & & & & UNE EN 1015-10 & UNE EN 1015-10 \\
\hline Lime mortar & 40 & 40 & 160 & 1810 & 20.5 \\
\hline
\end{tabular}

The first consideration, from the test is that, in the two types of bricks in the first stage the water absorbed is very similar in proportion, but from a certain point and for a short period the brick tiles specimen absorbs less water and in a third phase the amount of both tends to a horizontal asymptote. In the first stage the brick tiles absorbs more water which also happens in the suction test according to UNE-EN 772-11. As for the mortar it is apparent that water absorption is slower, the first part of the graph is less steep and less water is absorbed.

\subsection{Capillary water absorption in walls}

The results of tests are to be compared with the results of water absorption of the materials in the brick walls. First, the data of humidity probes taken during the months that have lasted the test have been transferred to Figure 4 (brick tile wall) and Figure 5 (modern brick wall). In them you can see how the process of capillary absorption develops very rapidly up to the third probe and slows down at the probes 4, 5 and 6. It's interesting the behavior of row 3 in both walls, though it ends up reaching the same moisture content, it takes longer in the modern brick - five times - to achieve it. This would be because of its lower initial absorption rate compared to the brick tiles.

Moisture variations of the probes located in the upper rows are influenced by the conditions inside the test room in which it is performed, because of hygroscopic variations absorption / desorption of water vapor in the surrounding atmosphere. Observing the data of the probes in Table 4, before demolition, it's clear that the temperature is higher the lower the relative humidity and this process is very similar in the two walls. This happens due to desorption: the higher the moisture content of the wall, the higher the humidity difference between the external environment and the wall, so the desorption is greater, which causes the temperature to drop.

This information is important because the same thing happens on the surface, and images taken with a thermal camera can clearly show that the temperature at the base of the walls is lower than the area above where it is similar to that of the environment, 1 to 2 tenths of a degree lesser. In Figure 6 are the elevations of the walls before demolition. The thermal image is attached to the elevation of the two walls: brick tiles on left and on the right modern brick. The lower the temperature the higher content of water in the wall and this corresponds with the data from the probe in Table 3. If the image is
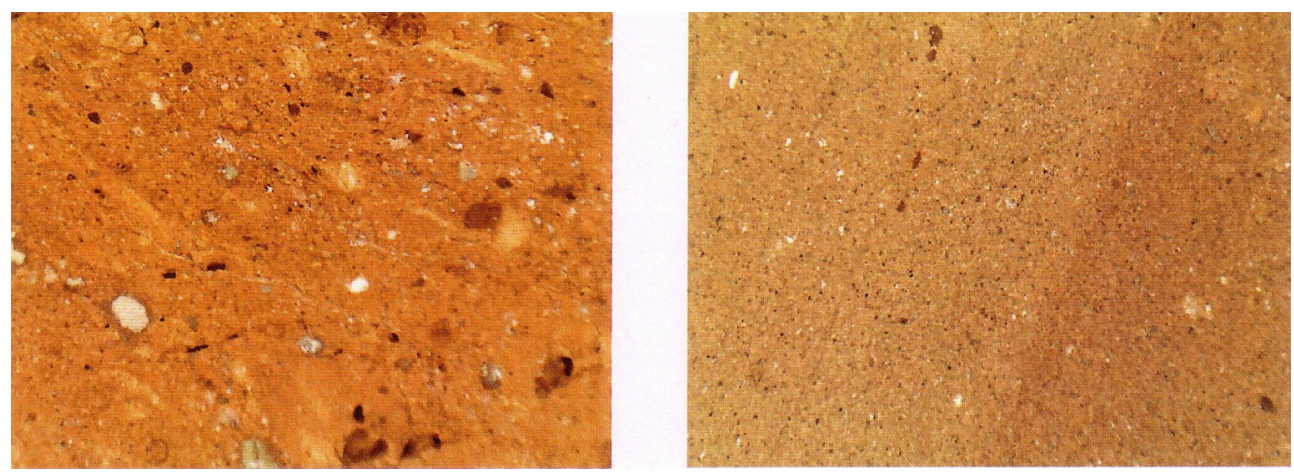

FIGURE 2. On the left a section of a brick tiles and right section of a modern brick made with microscope with 100x magnification. 
TABLE 2. Results of water absorption tests of the materials according to UNE

\begin{tabular}{|c|c|c|c|c|}
\hline \multirow{4}{*}{ Time } & \multicolumn{2}{|c|}{ UNE EN 15801} & \multirow{2}{*}{$\begin{array}{c}\text { UNE EN 772-11 } \\
1 \mathrm{~min} \\
\end{array}$} & \multirow{2}{*}{$\begin{array}{c}\text { UNE EN } 1015-18 \\
10 \text { to } 90 \mathrm{~min} \\
\end{array}$} \\
\hline & & & & \\
\hline & $\mathbf{Q}_{\mathrm{i}}$ & $\mathrm{AC}$ & Cwi,s & $\mathrm{C}$ \\
\hline & $\mathrm{kg} / \mathrm{m}^{2}$ & & $\mathbf{k g}\left(\mathrm{m}^{2} \cdot \min \right)$ & $\operatorname{kg}\left(\mathrm{m}^{2} \cdot \min ^{0.5}\right)$ \\
\hline Brick tile & 59.01 & 0.22 & 1.6 & - \\
\hline Modern brick & 63.26 & 0.18 & 0.9 & - \\
\hline Lime mortar & 20.47 & 0.12 & 0.64 & 1.22 \\
\hline
\end{tabular}

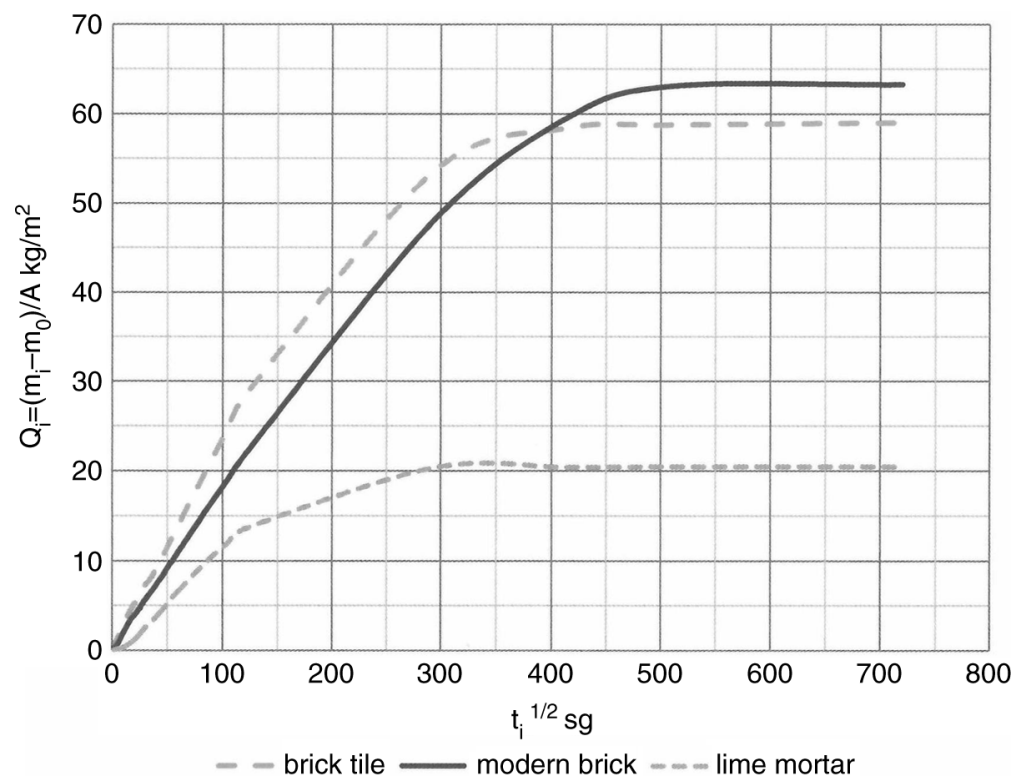

FIGURE 3. Graph of the values obtained from the test UNE EN 15801 of the materials.

captured from a shorter distance, you can see the difference in water content between the bricks and the mortar.

As noted above the measurement of the moisture with the probes provides information about the process of capillary water rise but provides no information on the amount of water absorbed, as the probes indicated $99 \%$ relative humidity when the brick had absorbed less than $10 \%$ of the total water that it may contain, as shown by the tests. However, this measurement allows us to know the timing of the capillary rise process as well as the oscillations due to changes in temperature and the humidity in the environment.

To understand the process capillary moisture rise, the walls were demolished and brick and mortar specimens were tested, procedure already described, and thus know the amount of water absorbed. The data obtained is reflected in the following diagrams by colors and figures that represent the elevations of the two types of walls, it's in $1 / \mathrm{m}^{3}$ to be able to compare the data from the two walls (Figure 7). These units have been chosen since Peixoto (13) studied the capillary absorption in walls as $\mathrm{W}_{\text {sat }}$ saturation moisture content in $\mathrm{kg} / \mathrm{m}^{3}$, and these units can better compare to the results obtained of the densities of the three different materials. Because we are using water 1 has been adopted as a unit instead of $\mathrm{kg}$.

As can be seen by comparing Figures 6 and 7 , the image of the thermal camera is indicating quickly and fairly precise the areas of the wall where the moisture content is higher, thus demonstrating that the imager is an adequate tool for diagnosis of moisture problems in buildings. In both cases, on brick and mortar, it can be seen that in the upper area the material is not completely dry but has a small amount of water, due to ambient humidity. To better compare the results of studies of the materials and the walls we have moved data from all tests to Table 4 in which the moisture content is expressed in $1 / \mathrm{m}^{3}$. In one column test values according to UNE EN 15801, located on the right UNE EN 772-11 tests which have also been made with mortar specimens, even 


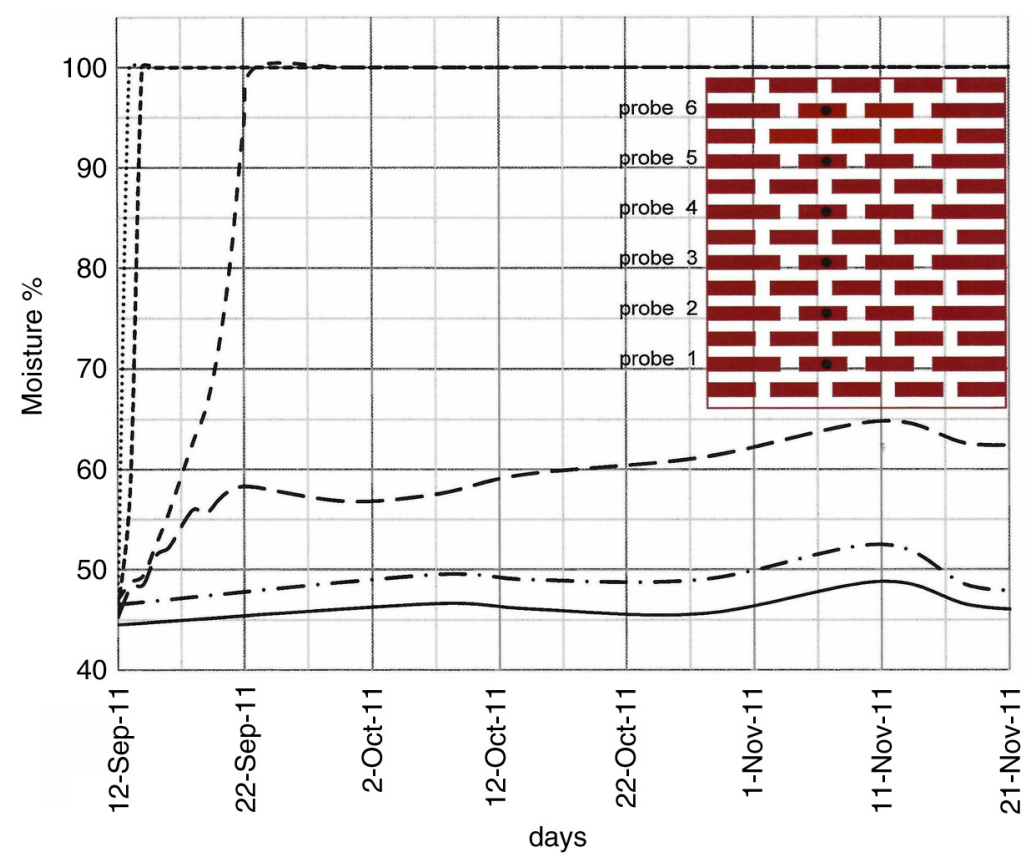

........ probe 1 ---- probe 2 - - probe $3-$ probe $4-$ probe $5-$ probe 6

Figure 4. Brick tile Wall. RH values (\%) of probes placed in the holes of the brick courses.

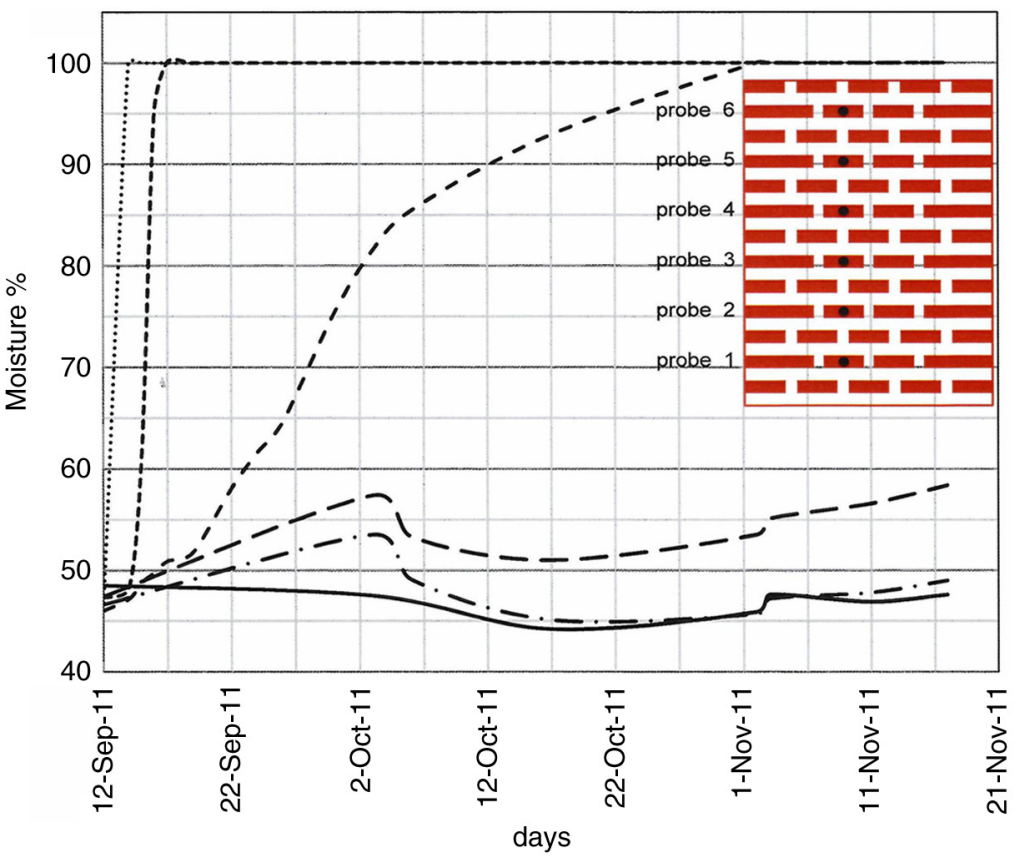

........ probe 1 -..-p probe 2 - - probe 3 - probe 4 - probe 5 probe 6

FIgURE 5. Modern brick wall. RH values (\%) of probes placed in the holes of the brick courses.

though it is a test meant for bricks. In the following columns, with mean values, are the moisture content of the lower courses of bricks and mortar joints of the two walls, being the ones closest to the wet base. The last column shows the values of the climate chamber test indicating the water content of the material because of the ambient water vapor. 
TABLE 3. Temperature and relative humidity from the probes from the walls

\begin{tabular}{lllllll}
\hline & & \multicolumn{2}{c}{ brick tile } & & \multicolumn{2}{c}{ modern brick } \\
\cline { 3 - 4 } \cline { 6 - 7 } & & $\mathbf{T}^{\circ} \mathbf{C}$ & $\mathbf{H r} \%$ & & $\mathbf{T}^{\circ} \mathbf{C}$ & $\mathbf{H r} \%$ \\
\hline course 12 & probe 6 & 22.1 & 40.1 & & 22.2 & 40.1 \\
course 10 & probe 5 & 21.9 & 44.8 & & 22.0 & 41.5 \\
course 8 & probe 4 & 21.4 & 67.3 & & 21.3 & 61.9 \\
course 6 & probe 3 & 21.0 & 99.9 & & 21.0 & 99.9 \\
course 4 & probe 2 & 19.9 & 99.9 & & 19.9 & 99.9 \\
course 2 & probe 1 & 19.9 & 99.9 & & 19.9 & 99.9 \\
\hline
\end{tabular}

The tests whose results are closer to that of the walls are the ones made according to the UNE EN 15801 standard and the absorption value indicating the process in brick masonry is of the brick because as can be seen the values of water capillary absorption by mortar specimens is different in the two walls even when they were executed at the same time and with the same type of mortar. Values of water absorption in the lower courses are superior in the tests on walls than in the tests performed under the UNE standards which is somewhat predictable as the brick and mortar specimens of the wall are confined, and the specimens materials present only one side in contact with the moisture source and the rest in contact with air, however, the results of tests of the standard UNE 15801 have a very similar proportion: in the case of brick tiles they absorb $11 \%$ more water in the wall and the modern brick absorbs $12 \%$ more water.
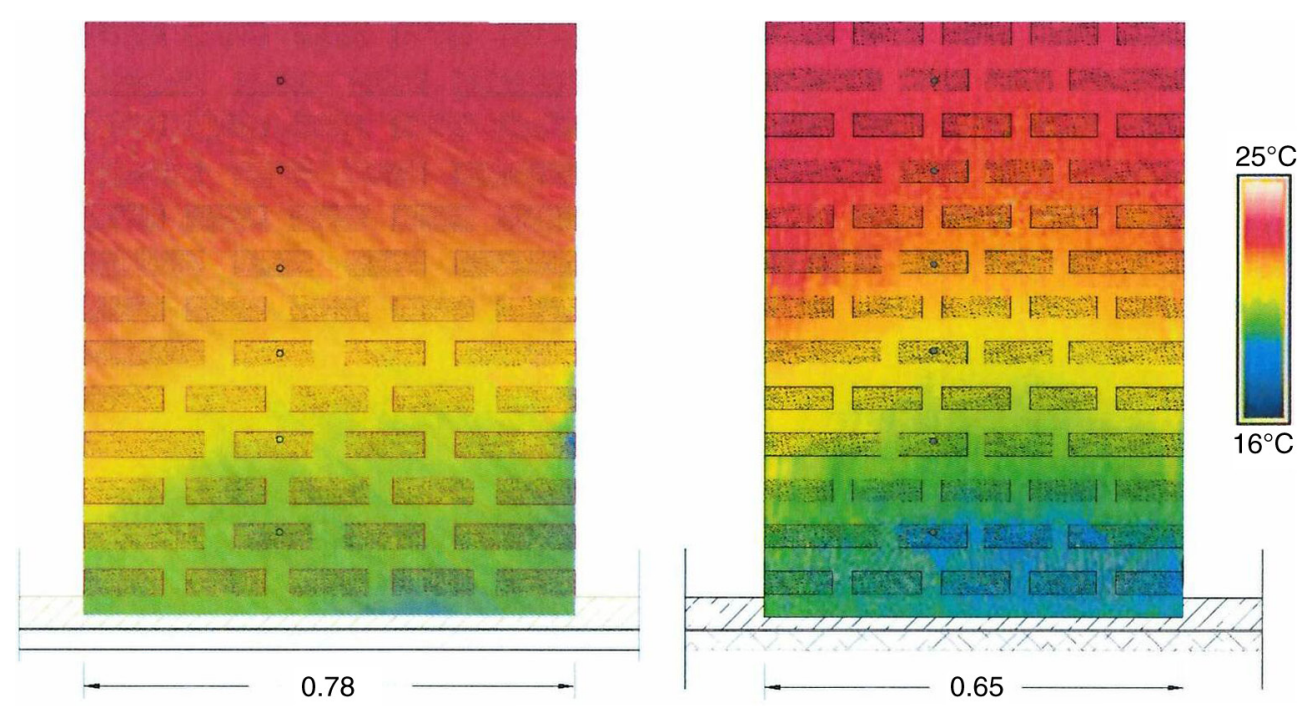

FIGURE 6. Images from the thermal camera: brick tiles on left and on the right modern brick.
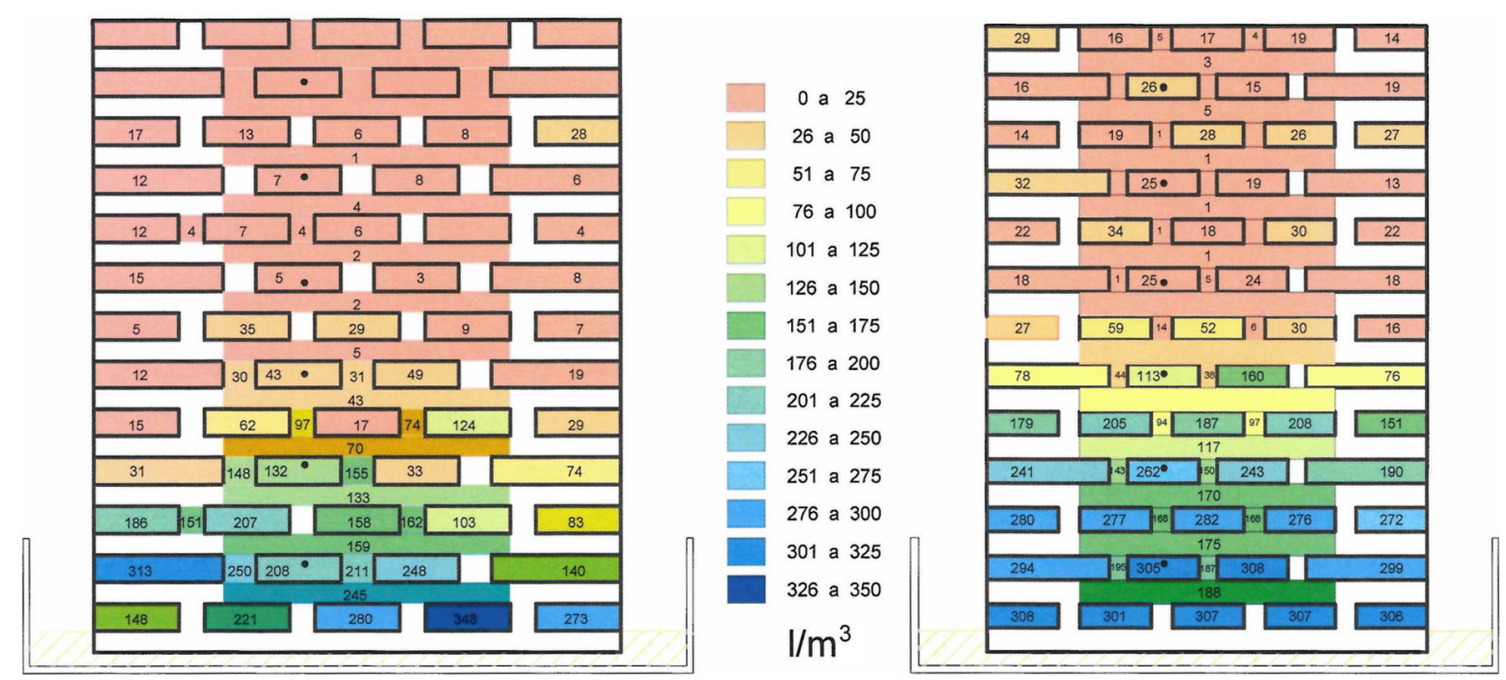

FIGURE 7. Moisture content in the bricks and mortar specimens after demolition $\left(1 / \mathrm{m}^{3}\right)$ : left brick tiling wall and right wall modern brick. 
TABLE 4. Results of the various tests done on the materials

\begin{tabular}{|c|c|c|c|c|c|}
\hline & \multirow[b]{2}{*}{ UNE EN 15801} & \multirow[b]{2}{*}{ UNE EN 772-11 } & \multicolumn{2}{|c|}{ test brick wall } & \multirow[b]{2}{*}{ test climatic chamber } \\
\hline & & & brick tile & modern brick & \\
\hline & 6 days & $1 \mathrm{~min}$ & \multicolumn{2}{|c|}{ course 1, bed joint 2} & $\mathrm{~T}=20^{\circ} \mathrm{C} \mathrm{Hr}=50 \%$ \\
\hline & $\mathbf{W}_{\text {sat }}$ & $\mathbf{W}_{\text {sat }}$ & \multicolumn{2}{|c|}{ W } & $\mathbf{W}$ \\
\hline & $1 / \mathrm{m}^{3}$ & $1 / \mathrm{m}^{3}$ & \multicolumn{2}{|c|}{$1 / \mathrm{m}^{3}$} & $1 / \mathrm{m}^{3}$ \\
\hline brick tile & 228 & 33 & 254 & & 2.5 \\
\hline modern brick & 271 & 24 & & 306 & 9.0 \\
\hline lime mortar & 146 & 16 & 245 & 188 & 1.3 \\
\hline
\end{tabular}

If the values in the right hand column of the table are compared with the values of the stretcher course and bed joints it can be seen that the moisture present is not due to the water rising through capillary absorption and reaching this point but due to the water vapor in the ambient that entered and condensed in the materials.

\section{CONCLUSION}

When comparing the results of tests conducted on the material: bricks and mortar and brick walls:

- It has been shown that tests on bricks made according to the standard "UNE-EN 15801 Conservation of cultural property - Test methods - Determination of water absorption by capillarity" can obtain information representing the behavior of the brick walls against the rise of capillary water.

- The tests on materials according to UNE EN 15801, UNE EN 772-11 and tests done using moisture probes for the process of capillary rise of water in walls indicate that the modern brick absorbs more water than the brick tile and mortar at the end of the process, but water absorption in brick tiles is faster at the beginning.

- The mortar has different absorption values in the two walls suggesting that absorption value of the brick, which is the highest, is more relevant.

With the various tests which were carried out it would be possible to assess the level reached by ascending capillary water from the base of a brick wall of a building using the data that can be obtained with:

- Moisture probes that permit the determination of how far the capillary water has risen, and is approximately where the probe inserted into the wall presents the same data as the one on the outside of the wall.

- Thermal images, since the surface temperatures are related to the moisture content of the wall.

- The tests according to the EN 15801 with which information about absorption of the material is obtained. One could make the extraction of large brick specimens thick $\mathrm{x}$ thickness $\mathrm{x}$ at three different levels, test them, and calculate the water content of the wall.

\section{ACKNOWLEDGEMENTS}

The tests were carried out with the aid granted by the Ministry of Economy and Competitiveness of Spain to Research Project entitled "Protection against moisture in old brick masonry walls. Study of the use of repellents in their restoration" BIA2010-19245 in the construction laboratory of the Escuela Técnica Superior de Arquitectura de la Universidad de Valladolid.

\section{REFERENCES}

1. Mason G. (1974) Rising damp, Build SCI 9, 227-231. http://dx.doi.org/10.1016/0007-3628(74)90021-8.

2. Hall, C.; Hoff, W.D. (2007) Rising damp: capillary rise dynamics in walls, Proceedings of The Royal Society A-Mathematical Physical And Engineering Sciences 463, 1871-1884, http://dx.doi.org/10.1098/rspa.2007.1855.

3. Rirsch, E.; Zhang, Z. (2010) Rising damp in masonry walls and the importance of mortar properties, Construc. Build. Mat. 24, 1815-1820, http://dx.doi.org/10.1016/j. conbuildmat.2010.04.024.

4. Peixotode Freitas, V.; Torres, M.I.; Guimarães, A.S. (2008) Humidade Ascensional, 106, Faculdade de Engenharia da Universidade do Porto, Porto.

5. Torres, I.; Peixoto de Freitas, V. (2010) The influence of the thickness of the walls and their properties on the treatment of rising damp in historic buildings, Construc. Build. Mat 24, 1331-1339, http://dx.doi.org/10.1016/j. conbuildmat.2010.01.004.

6. Peixoto, V. (2012) Tratamiento da humidade ascensional $\mathrm{em}$ edifícios antigos, $4^{\circ}$ Congreso de patología y rehabilitación de edificios. PATORREB 2012, 40.

7. De Villanueva, J. (1827) Arte de Albañilería o instrucciones para los jóvenes que se dediquen a él, en que se trata de las herramientas necesarias al albañil, formación de andamios, y toda clase de fábricas que se puedan ofrecer, Madrid.

8. Norma UNE EN 772-16 (2001) Método de ensayo para piezas de fábrica de albañilería. Parte 16: determinación de las dimensiones.

9. UNE EN 772-13 (2001) Método de ensayo de piezas para fábrica de albañilería. Parte 13: Determinación de la densidad absoluta seca y de la densidad aparente seca de piezas para fábrica de albañilería (excepto piedra natural).

10. UNE EN 772-3 (1999) Método de ensayo para piezas de fábrica de albañilería. Parte 3: Determinación del volumen 
neto y del porcentaje de huecos por pesada hidrostática de piezas de arcilla cocida para fábrica de albañilería.

11. Camino M.S.; León F.J.; Llorente A.; Olivar J.M. (2012) Propuesta de ensayo para evaluar las barreras químicas para evitar la subida del agua del terreno en fábrica, $4^{\circ}$ Congreso de patología y rehabilitación de edificios. PATORREB 2012, 163.

12. Fort, R.; Álvarez de Buergo, M.; López de Azcona, M.; Mingarro, F.; Varas, M.; Soriano, J. (2004) Caracterización de la Fábrica de Ladrillo del Palacio del Infante Don Luis, Boadilla del Monte, Madrid, Boletín de la Sociedad Española de Cerámica y Vidrio, 43 [2], 578-582, http:// dx.doi.org/10.3989/cyv.2004.v43.i2.599.

13. Setti, M.; Lanfranchi, A.; Cultrone, G.; Marinoni, L. (2012) Archaeometric investigation and evaluation of the decay of ceramic materials from the church of Santa Maria del Carmine (Pavia, Italy), Mater. Construcc. 62, [305], 79-98, http://dx.doi.org/10.3989/mc.2011.62310. 